\title{
That's disturbing! An exploration of the bacteriophage biology of change
}

\author{
Heather K. Allen ${ }^{1 *}$ and Stephen T. Abedon ${ }^{2 *}$ \\ ${ }^{1}$ Agricultural Research Service, United States Department of Agriculture, National Animal Disease Center, Ames, IA, USA \\ 2 Department of Microbiology, The Ohio State University, Mansfield, OH, USA \\ *Correspondence: heather.allen@ars.usda.gov; abedon.1@osu.edu
}

Edited by:

John R. Battista, Louisiana State University and A \& M College, USA

Keywords: virus ecology, ecological disturbance, phage-bacteria interactions

The nature of life is change. Organisms change developmentally, morphologically, and physiologically, and they also modify their environments in the process. Such change can be gradual, abrupt, or even imperceptible components of steady states. Temporally, change can range from deterministic and regular processes to stochastic and unusual events. Unusual changes can result from relatively frequent occurrences, such as particularly devastating storms or instead highly uncommon events such as volcanic eruptions, ice ages, and asteroid impacts.

The scale of environmental change can be local or global, seasonal or climatic. The change can be caused by organisms, including as incidental consequences of their activities, such as our own anthropogenic influences on ecosystems and climate. Responses of organisms to change ranges from behavioral to physiological to developmental, and can occur over ecological as well as evolutionary time scales. The study of ecologically relevant physiological responses is described as physiological ecology, or ecophysiology, while evolutionary responses represent Darwinian evolution.

Among effectors of change are parasites, including viruses. In considering the viruses of bacteria-bacteriophages or phageschange to hosts can vary from devastating lytic infections to simple genetic modification via lysogeny. In between are phages that are released from bacteria chronically, with productively infected bacteria continuing to replicate. Phage-induced change also can range from seemingly cosmetic chromatin rearrangements, as triggered by phage $\mathrm{T} 2$ during infection of Escherichia coli (Murray et al., 1950) to lysogenic conversion as can result in phage-encoded augmentation of bacterial pathogenesis (Addy et al., 2012). Bacteria also can change in response to phage infection, becoming immune to infecting phages by producing virus-specific interfering RNAs that are associated with CRISPR/Cas systems (Richter et al., 2012).

Change within the context of phages themselves is often more subtle. Phage virions can diffuse or be moved between microenvironments or ecosystems, resulting in changes in abiotic conditions. These environmental changes can cause physiological changes to their adsorption abilities (Conley and Wood, 1975). Phage physiology also changes dramatically as phages transition from their virion or free state to that of infecting bacteria, and then again from their phage-infecting form back to the free virion state. These transitions sometimes include a state of quiescence called pseudolysogeny. These pseudolysogenic states can be brought about by environmental conditions, such as bacterial starvation, and might help to promote phage survival (Ripp and Miller, 1997).

Examination of populations, communities, and entire ecosystems reveals that phages play integral roles in both eliciting and responding to disturbances (Figure 1). Phage biology and the relative impact of phages on bacterial populations can change, particularly as phage densities increase from those causing lower versus higher multiplicities of infection (Abedon, 2012). Environmental change in turn can impact viral population densities, including in terms of antibiotic induction of prophages (Allen et al., 2011). Bacterial fitness can change not just with phage quantity but also with phage quality, with greater bacterial fitness costs potentially associated with bacterial evolutionary responses to predation by multiple versus individual phage types (Koskella et al., 2012).

Selection on phages acts primarily on host acquisition, on rates of progeny production, and on survival until host acquisition again becomes a possibility. Suggesting an existence of tradeoffs associated with the optimization of these organismal properties, phage infection strategies may change in their effectiveness, pleiotropically, as phages change from infecting one bacterial strain to another (Duffy et al., 2006). Changes in the abundances of phages and other viruses in complex communities can occur seasonally in estuarian habitats (Winget et al., 2011) or in halophilic viral communities in response to environmental stressors (Santos et al., 2011). Phage abundance also can vary as a function of bacterial abundance, and in turn the cost to bacteria of phage sensitivity can increase as a function of phage abundance. Bacterial existence at high densities thus can result in phage-induced catastrophic changes in bacterial densities, a phenomenon that has been dubbed, "Killing the winner" (Rodriguez-Valera et al., 2009).

On the level of ecosystems, phages can be key contributors to the mineralization of nutrients as they solubilize host bacteria via lysis. As such they contribute to the primary ecological process of soils, that of decomposition and decay. In aquatic environments, phages potentially impact global carbon cycling by short circuiting the movement of carbon and energy to heterotrophic bacteria rather than from cyanobacteria to consumer eukaryotes 


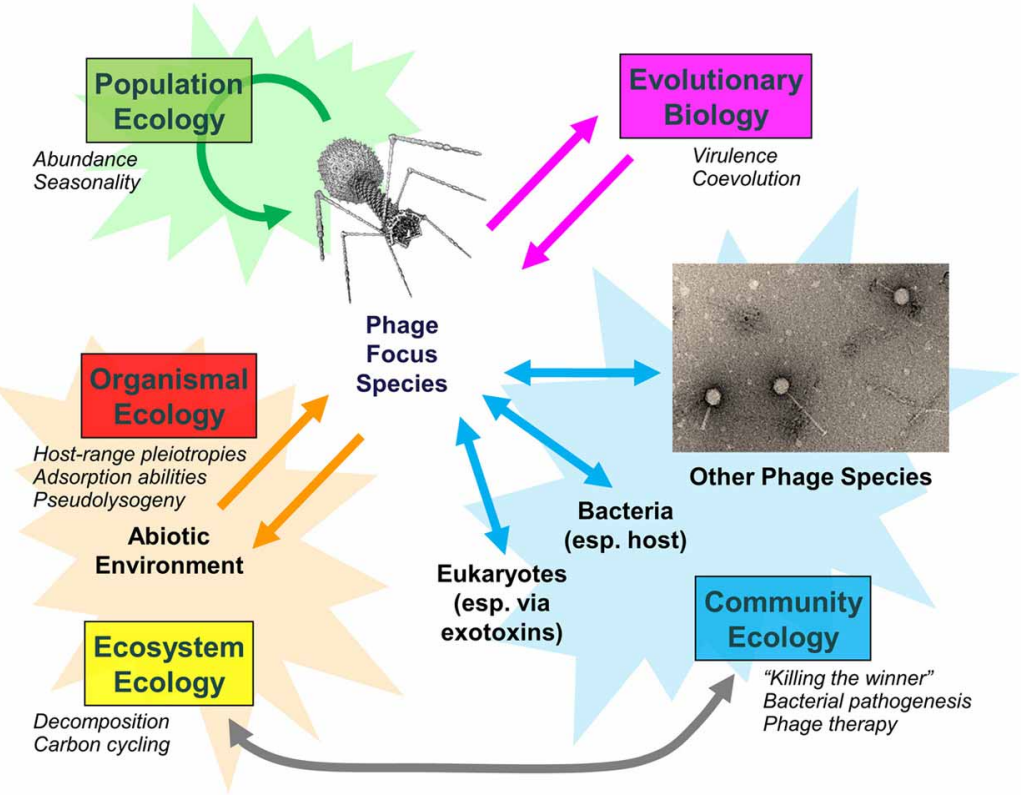

FIGURE 1 | Bacteriophage population, community, and ecosystem impacts. Examples of phage-associated changes are italicized. Adapted from Abedon (2009).

(Wilhelm and Suttle, 1999). In addition, phages can be added deliberately to environments to motivate change, as seen with phage-mediated biocontrol or phage therapy.

Change thus represents an ongoing and intrinsic aspect of phage biology, with phages both affecting and effecting organismal- population-, community-, ecosystem-, and even global environmental change. In this Research Topic we consider

\section{REFERENCES}

Abedon, S. T. (2009). Phage evolution and ecology. Adv. Appl. Microbiol. 67, 1-45. doi: 10.1016/S0065-2164(08)01001-0

Abedon, S. T. (2012). Spatial vulnerability: bacterial arrangements, microcolonies, and biofilms as responses to low rather than high phage densities. Viruses 4, 663-687. doi: 10.3390/ v4050663

Addy, H. S., Askora, A., Kawasaki, T., Fujie, M., and Yamada, T. (2012). The filamentous phage QRSS1 enhances virulence of phytopathogenic Ralstonia solanacearum on tomato. Phytopathology 102, 244-251. doi: 10.1094/PHYTO-10-11-0277

Allen, H. K., Looft, T., Bayles, D. O., Humphrey, S., Levine, U. Y., Alt, D., et al. (2011). Antibiotics in feed induce prophages in Swine fecal microbiomes. MBio 2:e0026011. doi: 10.1128/mBio.00260-11

Conley, M. P., and Wood, W. B. (1975). Bacteriophage T4 whiskers: a rudimentary environment-sensing device. Proc. Natl. Acad. Sci. U.S.A. 72, 3701-3705. doi: 10.1073/pnas.72. 9.3701

Duffy, S., Turner, P. E., and Burch, C. L. (2006). Pleiotropic costs of niche expansion in the RNA bacteriophage $\Phi 6$. Genetics 172, 751-757. doi: 10.1534/genetics. 105. 051136

Koskella, B., Lin, D. M., Buckling, A., and Thompson, J. N. (2012). The costs of evolving resistance in heterogeneous parasite environments. Proc. R. Soc. Lond. B Biol. Sci. 279, 1896-1903. doi: 10.1098/rspb.2011.2259

Murray, R. G., Gillen, D. H., and Heagy, F. C. (1950). Cytological changes in Escherichia coli produced by infection with phage T2. J. Bacteriol. 59, 603-615.

Richter, C., Chang, J. T., and Fineran, P. C. (2012). Function and regulation of clustered regularly interspaced short palindromic repeats (CRISPR) / CRISPR associated (Cas) systems. Viruses 4, 2291-2311. doi: 10.3390/v4102291

especially the impact of environmental change on communities and ecosystems as those changes may be propagated through phages, gene transfer agents, and viruses of other microorganisms.

\section{ACKNOWLEDGMENTS}

USDA is an equal opportunity provider and employer.

Ripp, S., and Miller, R. V. (1997). The role of pseudolysogeny in bacteriophage-host interactions in a natural freshwater environment. Microbiology 143, 2065-2070. doi: 10.1099/00221287-143-6-2065

Rodriguez-Valera, F., MartinCuadrado, A. B., Rodriguez-Brito, B., Pasic, L., Thingstad, T. F., Rohwer, F., et al. (2009). Explaining microbial population genomics through phage predation. Nat. Rev. Microbiol. 7, 828-836. doi: 10.1038/nrmicro2235

Santos, F., Moreno-Paz, M., Meseguer, I., Lopez, C., Rossello-Mora, R., Parro, V., et al. (2011). Metatranscriptomic analysis of extremely halophilic viral communities. ISME J. 5, 1621-1633. doi: 10.1038/ismej.2011.34

Wilhelm, S. W., and Suttle, C. A. (1999). Viruses and nutrient cycles in the sea. Bioscience 49, 781-788. doi: $10.2307 / 1313569$

Winget, D. M., Helton, R. R., Williamson, K. E., Bench, S. R., Williamson, S. J., and Wommack, K. E. (2011). Repeating patterns of virioplankton production within an estuarine ecosystem. Proc. Natl. Acad. Sci. U.S.A. 108, 11506-11511. doi: $10.1073 /$ pnas. 1101907108

Received: 05 September 2013; accepted: 13 September 2013; published online: 14 November 2013.

Citation: Allen HK and Abedon ST (2013) That's disturbing! An exploration of the bacteriophage biology of change. Front. Microbiol. 4:295. doi: 10.3389/ fmicb.2013.00295

This article was submitted to Evolutionary and Genomic Microbiology, a section of the journal Frontiers in Microbiology.

Copyright (c) 2013 Allen and Abedon. This is an open-access article distributed under the terms of the Creative Commons Attribution License (CC BY). The use, distribution or reproduction in other forums is permitted, provided the original author(s) or licensor are credited and that the original publication in this journal is cited, in accordance with accepted academic practice. No use, distribution or reproduction is permitted which does not comply with these terms. 